\title{
UNEXPECTED EMERGENCE OF NEWCASTLE DISEASE VIRUS IN VERY YOUNG CHICKS
}

\author{
Z. POSPIŚIL, Dagmar ZENDULKOVÁ* and B. ŠMÍD* \\ Department of Veterinary Epidemiology, University of Veterinary Science, 61242 Brno \\ * Veterinary Research Institute, 62132 Brno
}

Received September 14, 1990

\begin{abstract}
Pospíšil Z., Dagmar Zendulková, B. Šmíd: Unexpected Emergence of Newcastle Disease Virus in Very Young Chicks. Acta vet. Brno 60, 1991: 263-270.

Lentogenic Newcastle disease virus (NDV) strains were demonstrated by culture and electron microscopically in the gut contents of very young, non-vaccinated chickens from hatching up to day 25 . The same virus was demonstrated even in chicken embryos despite the presence of maternal antibodies both in yolk extracts, and in hatched chicks. NDV disappeared from the organism of infected chickens without inducing antibody formation. Post-vaccination antibody titres were very low and various in chickens previously infected with NDV. Possible transovarian transmission of NDV is discussed.
\end{abstract}

Nerwcastle disease virus, lentogenic strains, chickens, transovarian transmission, vaccination

Newcastle disease (ND) has been controlled in Czechoslovakia successfully by effective preventive and prophylactic measures and does not pose a serious veterinary or economic problem at present. Our recent investigations, aimed at the prevalence of emerging virus infections, have revealed, however, the presence of haemagglutinating agents, which were preliminarily classified as paramyxoviruses, by electron microscopy and subsequently identified as lentogenic Newcastle disease virus (NDV) strains.

The viruses were detected rather unexpectedly, in 15- to 25-day-old chickens with various clinical signs. Some of them were affected with a slight head oedema, sinusitis or conjunctivitis, others with hyperaemia of the digestive tract mucosa. Quite often NDV was isolated from chickens showing no clinical signs of infection.

A similar symptomless form, caused by lentogenic NDV strains and diagnosed rather accidentally in most cases, was described by Lancaster (1981). In a review published by Hanson (1984), the condition was referıed to as an asymptomatic enteric form of NDV.

Infections with lentogenic NDV strains without clinical signs and morphological lesions had been described also in Australia by French et al. (1967) and Simmons (1967). Recently lentogenic NDV strains were isolated from 3- to 5-week old chickens in Hungary by Erdei et al. (1988). The authors explain their findings as a persistence of the vaccinal strain, because the chickens had been immunized with a live, La Sota strain vaccine 1 to 3 weeks before the examination.

In our investigations, however, anamnestic data from many farms, obtained from field veterinarians, were uniform: chickens have not yet been immunized against ND and parent flocks are kept in permanent immunity. Therefore, basing on our preliminary results, we started to investigate the occurrence of paramyxoviruses in chickens in detail with the aim to identify the isolates more precisely, to determine the time of their first occurrence, to demonstrate contingent antibody response to the infection and to follow antibody formation after vaccinaiton.

\section{Materials and Methods}

1. Chickens and collection of samples

Initially 15- to 30-day-old sick chickens from farms affected with various health problems were selected. Most of them were laying hybrids, a smaller part were meat hybrids. After the surprising 
isolation of paramyxoviruses, we concentrated on laying hybrids only. Later the experiments aimed at the isolation of paramyxoviruses were done using 1- to 42-day old birds. Day-old chicks were collected in hatcheries, the rest was kept either in farms or in the premises of our institute. Antibody responses to infection or immunization were investigated up to the age of 4 months.

Parenchymatous organs, trachea and gut contents, in some cases also gut mucosa scrapings, were collected for virological examinations. A $10 \%$ suspension prepared from these organs in Earle's medium containing $1000 \mathrm{I}$. U. penicillin and $1000 \mu \mathrm{g}$ streptomycin was left to stand for 4 hours, then centrifuged at $3600 \times \mathrm{G}$ and $4{ }^{\circ} \mathrm{C}$ for 30 minutes and finally filtered through a $0.22 \mu \mathrm{m}$ pore filter. Blood samples for serological examinations were collected from vena ulnaris or from the heart.

\section{Virus isolation}

SPF chicken embryos (Phylaxia Budapest) were used in several isolation experiments, but most experiments were done on conventional chicken embryos from a small farm free of antibodies to NDV and other poultry infections and non-vaccinated against ND.

Intra-allantoic inoculation of 9- to 10-day-old embryos and of chicken embryo fibroblast cultures were performed in the usual manner (Plate I, Fig. 1). Cell cultures of fibroblasts were also prepared from eggs collected in a breeder flock in which the NDV-positive chickens were identified. The cultures were examined for cytopathic effect (CPE), haemadsorption and electronmicroscopically.

3. Haemadsorption and haemagglutination

Allantoic fluid, collected 72 hours after inoculation of chicken embryos, and cell-free fluid, collected from inoculated cell cultures, were examined by the haemagglutination test. Briefly, $0.05 \mathrm{ml}$ of serial twofold dilutions of allantoic fluid with PBS was pipetted into round-bottomed microplate wells and mixed with an equal volume of $0.5 \%$ hen erythrocyte suspension. The plates were left to stand for 1 hour at room temperature before the results were read. Culture medium from cell cultures was poured out and replaced by $0.4 \mathrm{ml}$ of a $0.5 \%$ suspension of hen erythrocytes for the haemadsorption test. After 30 minutes incubation at $37^{\circ} \mathrm{C}$, the content was gently washed with phosphate-buffered saline (PBS pH 7.2) and light microscope was used for the examination of adsorption of erythrocytes onto infected cells.

4. Electron microscopic examination of gut content and allantoic fluid

A $20 \%$ suspension in serum-free Earle's medium was prepared from gut contents for the direct demonstration of the virus. The suspension was centrifuged ar $3600 \times \mathrm{G}$ and $4{ }^{\circ} \mathrm{C}$ for 20 minutes and the supernatant was examined electron microscopically using $2 \%$ water solution of ammonium molybdate $(\mathrm{pH} \mathrm{7.0)}$ for negative staining. Allantoic fluid from infected chicken embryos was examined by the same technique without any pretreatment.

\section{Haemagglutination inhibition test}

The test was performed in a round-bottomed microplates. $0.025 \mathrm{ml}$ of serial twofold dilutions with PBS of examined sera, starting with $1: 5$, were incubated with 8 haemagglutinating units of the virus and after 60 minutes $0.05 \mathrm{ml}$ of $0.5 \%$ suspension of hen erythrocytes was added. The plates were left to stand 50 to 60 minutes at room temperature before the results were read.

6. Typing of paramyxovirus strains

The isolated paramyxovirus strains were further identified by the methods described by $\mathrm{Han}$ son (1980). The isolates were preliminarily identified as paramyxoviruses by haemagglutination and electron microscopy, and as NDV by the haemagglutination inhibition test using ND specific antisera. The isolated strains were further studied in detail partly in our laboratory and partly at the Department of Veterinary Science, University of Wisconsin, Madison, U.S.A., using the local ND specific antisera, comparative ND virus strains, SPF eggs and chicken embryo fibroblast cultures prepared thereof, and SPF chickens. The following tests were used for the typification of NDV strains: haemagglutination inhibition test with antisera to serotypes 1 through 9; mean death time of the minimum lethal dose (MDT/MLD); intracerebral pathogenicity for day-old chicks (ICPI); pathogenicity for 8-week-old chickens; ability to plaque on chicken embryo fibroblasts, thermostability of haemagglutinin; agglutination of mammalian erythrocytes.

\section{Dynamics of passive and active immunity}

The dynamics of maternal antibody levels were examined from hatching for 6 weeks in 5-day intervals. Moreover, antibody levels to NDV were checked in hens of the parental flock immunized with the inactivated vaccine Nobilis GNE (Intervet), as well as in yolk extracts of hatching eggs. Antibody response to repeated administration of the live vaccine AVIPEST (Bioveta, Nitra) was investigated in NDV-positive chickens from hatching in 3- to 4-week intervals. The results were compared with those obtained from chickens grown in a small farm, in which NDV had never been detected. 


\section{Results}

1. First isolations of the virus, its identification and typing

The first paramyxovirus strains were isolated from 15- to 25-day-old chickens, mostly affected with a mild upper respiratory tract disease, or hyperaemia of intestinal mucosa. An agent agglutinating hen erythrocytes tract detected in the allantoic fluid of chicken embryos, inoculated with an organ suspension or a filtrate of gut contents, occasionally in the first, but more frequently in the second or third passages.

A weak CPE was observed in the second and third passages in tissue cultures. The haemagglutinating activity was low and the virus was readily demonstrated by haemadsorption. CPE became more pronounced in subsequent passages only (Plate I, Fig. 2).

The haemagglutinating agent was first examined by electron microscopy and classified as a paramyxovirus on the basis of its characteristic morphologic conformation. Most frequently pleomorphic paramyxovirus particles with a diameter of 150 to $300 \mathrm{~nm}$, bearing approx. $8 \mathrm{~nm}$-long projections, were observed. Most of the virions were undamaged or only slightly damaged and therefore the internal structure was indistinct. Destroyed virions, showing a helical nucleocapsid with a diameter of approx. $18 \mathrm{~nm}$, were observed quite exceptionally (Fig. 3).

Identical paramyxoviruses were demonstrated in some cases by electron microscopy in the gut contents directly, i. e. without previous passaging in chicken embryos (Fig. 4).

All isolated paramyxovirus strains were classified as serotype 1 by the haemagglutination inhibition test using antisera to all 9 known avian paramyxovirus serological groups. Further testing according to criteria accepted for the typing of paramyxoviruses (Hans on 1980) yielded the following results:

MDT/MLD was 91.0-100.4, 98.4 and 47.2 in the isolated strains, La Sota and the velogenic strain Texas, resp. ICPI was $0.1-0.18,0.1$ and 1.87 in the isolated, La Sota and Texas strains, resp. None of the isolated strains produced clinical signs suggestive of ND in 8-week-old chickens. Only small plaques were formed in the presence of DEAE dextran and $\mathrm{Mg}^{++}$in chicken fibroblast culture inoculated with the isolated strains. None of the strains agglutinated hen erythrocytes after $15 \mathrm{~min}$. inactivation at $56^{\circ} \mathrm{C}$. While La Sota strain lost the agglutinating activity after $5 \mathrm{~min}$. inactivation, in the strain Coot, which is a typical representative of heat-stable paramyxoviruses, this activity persisted for more than $120 \mathrm{~min}$. Guinea-pig, mouse and horse erythrocytes were agglutinated by the isolated strains, too. The results of typing of the isolated paramyxovirus strains are summarised in Table 1 . All haemagglutinating isolates were identified as lentogenic NDV strains, closely related to the vaccinal strain La Sota.

By courtesy of Dr. D. Alexander from the Central Veterinary Institute, Weybridge, Surrey, England, the isolated strains were typified using monoclonal antibodies (Alexander et al. 1987). All isolated strains were classified as members of Group E of NDV, which is similar to the vaccinal strains Hitchner B1 and La Sota.

2. Age of virus-positive chickens

The first successful isolations were performed in 15- to 25-day-old chickens. With regard to the fact, that the flocks were subsequently vaccinated, and that the administration of vaccine could affect the results of isolation attempts, the youngest age group was selected for further isolation trials. 
Table 1

Results of typing of paramyxovirus strains

\begin{tabular}{|c|c|c|c|c|c|c|c|c|}
\hline \multirow[b]{2}{*}{$\begin{array}{c}\text { Strain } \\
\text { (isolate) }\end{array}$} & \multicolumn{4}{|l|}{. } & \multicolumn{2}{|c|}{ Criteria } & \multirow[b]{2}{*}{$\begin{array}{c}\text { Thermostability } \\
\text { of haemagglu- } \\
\text { tinin }\end{array}$} & \multirow[b]{2}{*}{$\begin{array}{l}\text { Agglutination } \\
\text { of mammalian } \\
\text { erythrocytes }\end{array}$} \\
\hline & $\begin{array}{l}\text { Serum } \\
\text { PMV-1 }\end{array}$ & $\begin{array}{l}\text { Sera } \\
\text { PMV- } \\
2 \text { to } 9\end{array}$ & $\begin{array}{l}\text { MDT/ } \\
\text { /MLD }\end{array}$ & ICPI & $\begin{array}{l}\text { Exp. infection } \\
\text { of 8-week old } \\
\text { chickens }\end{array}$ & $\begin{array}{c}\text { Plaque } \\
\text { formation }\end{array}$ & & \\
\hline $\begin{array}{l}X-85 \\
X-86 \\
\text { SL-88 } \\
\text { SL-93 } \\
\text { VB-200 } \\
\text { ST-203 } \\
\text { B-209 } \\
\text { La Sota } \\
\text { Texas }\end{array}$ & $\begin{array}{l}+ \\
+ \\
+ \\
+ \\
+ \\
+ \\
+ \\
+\end{array}$ & $\begin{array}{l}0 \\
0 \\
0 \\
0 \\
0 \\
0 \\
0 \\
0 \\
0\end{array}$ & $\begin{array}{r}91.0 \\
94.8 \\
92.9 \\
98.3 \\
97.0 \\
98.6 \\
100.4 \\
98.4 \\
47.2\end{array}$ & $\begin{array}{l}0.12 \\
0.11 \\
0.16 \\
0.18 \\
0.15 \\
0.12 \\
0.15 \\
0.10 \\
1.87\end{array}$ & $\begin{array}{c}\text { no symptoms } \\
\text { NE } \\
\text { NE } \\
\text { no symptoms } \\
\text { NE } \\
\text { no symptoms } \\
\text { NE } \\
\text { NE } \\
\text { NE }\end{array}$ & $\begin{array}{l}\text { small } \\
\text { small } \\
\text { small } \\
\text { small } \\
\text { small } \\
\text { small } \\
\text { small } \\
\text { small } \\
\text { big }\end{array}$ & $\begin{array}{l}<15 \mathrm{~min} . \\
<15 \mathrm{~min} . \\
<15 \mathrm{~min} . \\
<15 \mathrm{~min} . \\
<15 \mathrm{~min} . \\
<15 \mathrm{~min} . \\
<15 \mathrm{~min} . \\
\\
<5 \mathrm{~min} . \\
\text { strain Coot } \\
>120 \mathrm{~min} .\end{array}$ & $\begin{array}{l}+ \\
+ \\
+ \\
+ \\
+ \\
+ \\
+ \\
+ \\
\text { NE }\end{array}$ \\
\hline
\end{tabular}

NE - Not examined

MDT/MLD - Mean Death Time of the Minimum Lethal Dose

ICPI - Intracerebral Pathogenicity Index for Day-Old Chicks

NDV was detected also in much younger birds with no clinical signs of ND. The virus was present in large quantities in the gut contents even of day-old chicks collected from the hatchery and could be isolated from the gut content more readily than from organs. The virus was demonstrated both by inoculation of chicken embryos, and by electron microscopy. It was just this age group, in which the highest virus concentrations were found in the gut contents. The concentration decreased with advancing age and the virus was no more demonstrable by any of the methods used around day 25 after hatching (Table 2).

\section{Virus demonstration in hatching eggs}

NDV was demonstrated in hatching eggs from a breeder flock, which supplied NDV-positive chickens. A weak CPE was observed in chicken embryo fibroblast cultures after 3 to 4 days. The cells showed haemadsorbing activity and undiluted cell-free culture medium agglutinated hen erythrocytes. The presence of a paramyxovirus was confirmed by electron microscopy. Using this method, paramyxoviruses were demonstrated in gut suspension of 17 to 19-day-old chicken embryos, too.

Table 2

Dynamics of NDV concentration and maternal antibody titres in chickens

\begin{tabular}{|c|c|c|c|c|c|c|}
\hline \multirow{3}{*}{$\begin{array}{l}\text { Age } \\
\text { (days) }\end{array}$} & \multicolumn{4}{|c|}{ Virus demonstration } & \multirow{2}{*}{\multicolumn{2}{|c|}{$\begin{array}{l}\text { HI titre of } \\
\text { maternal antibodies }\end{array}$}} \\
\hline & \multicolumn{2}{|c|}{ Direct in gut content } & \multicolumn{2}{|c|}{ Isolation in $\mathrm{CE}$} & & \\
\hline & ELMI & HA & ELMI & HA & Range & Mean \\
\hline $\begin{array}{r}1 \\
5 \\
10 \\
16 \\
20 \\
25 \\
42\end{array}$ & $\begin{array}{r}t+t \\
++t \\
++ \\
+ \\
t \\
0 \\
0\end{array}$ & $\begin{array}{r}++ \\
+ \\
\pm \\
0 \\
0 \\
0 \\
0\end{array}$ & $\begin{array}{r}t+t \\
+++ \\
++ \\
++ \\
+ \\
0 \\
0\end{array}$ & $\begin{array}{r}t+t \\
++t \\
++ \\
+ \\
+ \\
0 \\
0\end{array}$ & $\begin{array}{c}1: 5-1: 80 \\
1: 5-1: 80 \\
1: 5-1: 40 \\
1: 5-1: 10 \\
1: 5-1: 10 \\
0-1: 5 \\
0\end{array}$ & $\begin{array}{r}41.2 \\
32.4 \\
19.0 \\
9.5 \\
3.8 \\
1.5 \\
0\end{array}$ \\
\hline
\end{tabular}

ELMI - electron microscopy

HA - haemagglutination

CE - chick embryo 


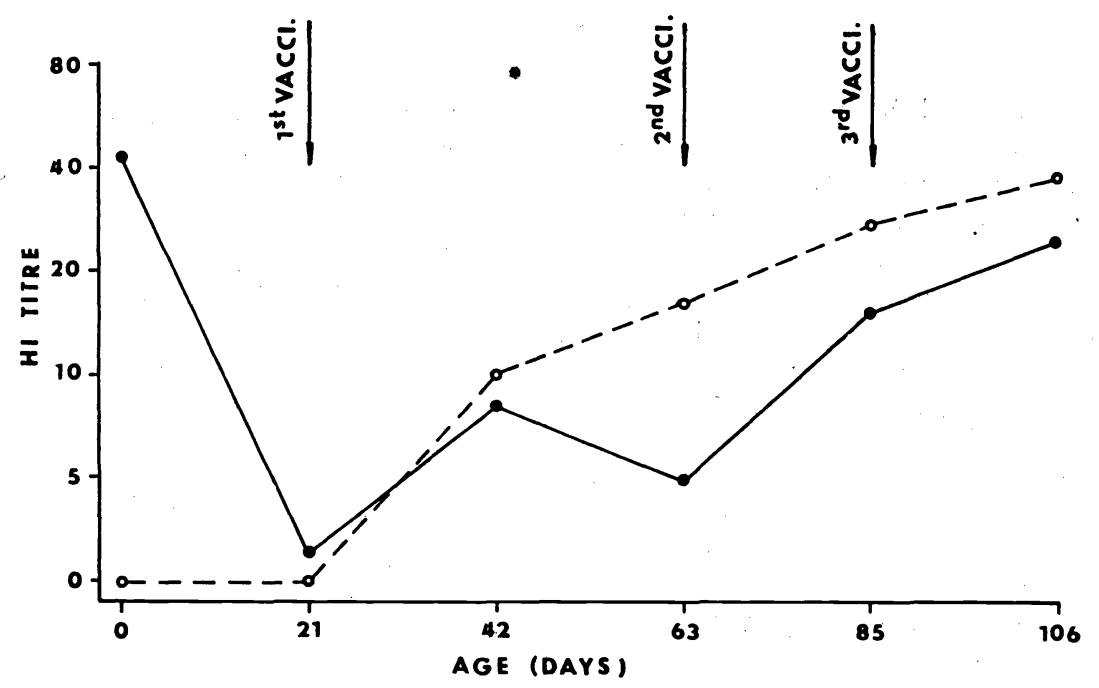

Fig. 5. Dynamics of maternal and post-vaccinal antibodies in chickens.

- chickens with previously demonstrated presence of NDV

$\mathrm{O}-\mathrm{O}$ chickens from a non-vaccinated flock, free of NDV

\section{Passive and active immunity}

Maternal antibodies to NDV were detected in blood serum of chicks, in which NDV was demonstrated after hatching. The initial average HI titre 1:41.2 decreased gradually and antibodies were no more demonstrable from days 20 to 25 after hatching (Table 2). Antibodies to NDV with an average titre 1:54 (range $1: 10$ to $1: 160$ ) were found in hens of the parent flock and titres between $1: 10$ and $1: 40$ were demonstrated in yolk extracts from hatching eggs.

Antibody response to administration of the live vaccine AVIPEST, performed at the age of approx. 21 days, was rather weak in chickens positive for NDV after hatching. The titres ranged between zero (40\% of birds) and $1: 40$ with a mean value of $1: 8.5$ three weeks after administration of vaccine. However, this value dropped to $1: 5$ during the next three weeks and therefore the chickens were treated with the vaccine again (Fig. 5). After another three weeks, the titres rose to $1: 5$ to $1: 40$ with a mean value of $1: 16$. The more pronounced increase of the mean value was due to the fact, that there were no more chickens with zero level in the re-vaccinated group. It was only the third administration, which resulted in a satisfactory mean titre of $1: 22.3$ (Fig. 5) Only a slightly better antibody response was observed in chickens from the same farm, which were kept in the institute and vaccinated as late as when 42-day-old.

The antibody response to vaccination was more pronounced in chickens from small farms free of NDV. The antibody titres ranged between $1: 10$ and $1: 40$ (mean $1: 17.6$ ) after the first, rose to $1: 10-1: 80$ (mean $1: 27.1$ ) after the second, and reached the mean value of $1: 38.8$ after the third administration (Fig. 5). 


\section{Discussion}

Lentogenic NDV strains were found quite unexpectedly in approx. 2- to 4-week-old chickens during the investigation of emerging virus infections in scraping poultry, although ND has been successfully controlled in this country. Rather unexpected were the findings of NDV in very young, and even day-old chicks and in chicken embryos from hatcheries. Remarkably enough, NDV was demonstrated not only by inoculation of chicken embryos and, to a lesser extent, cultures of chicken embryo fibroblasts, but also in the gut contents directly by electron microscopy. These findings not only confirm the results of isolation trials, but also exclude any laboratory contamination and support the possibility of transovarian transmission of the infection.

Information concerning the transovarian transmission of NDV is rather scarce (Fontaine et al. 1965; French et al. 1967; Fenner et al. 1987). This fact has been to a certain extent explained by Lancaster (1963), who considered such transmission epidemiologically less important, as the virus is usually so lethal for chick embryos that they rarely hatch. However, the possibility of such transmission has been confirmed experimentally by French et al. (1967), who also emphasized the danger resulting from the presence of a single infected chick in an incubator.

Similar findings of lentogenic NDV strains, corresponding to the La Sota strain, were described in 3- to 5-week-old chickens by Erdei et al. (1988). The chickens had been treated with a live, La Sota strain-containing vaccine 1 to 3 weeks before examination and the authors interpreted their findings in terms of persistence of the vaccinal strain. Mutation of the vaccinal strain has been suggested as the cause of the presence of lentogenic strains in young broilers by Hilbink (1987), too. In our experiments, however, NDV was demonstrated in chicks immediately after hatching, in which any vaccination could be excluded. Parent flocks were immunized with the inactivated vaccine Nobilis GNE before being transferred to the laying house and La Sota vaccine had been used for the first vaccination after hatching only.

When considering the transovarian transmission, we can explain neither the failure of maternal antibodies to neutralize the virus in the developing embryo, nor the fact, that the virus was no more demonstrable from days 20-25 after hatching. A remarkable coincidence was found in the disappearance of the virus and maternal antibodies. No active specific antibody formation was observed in non-vaccinated chickens during a 4- to 5-week period after the disappearance of the virus and maternal antibodies. The antibody response to the subsequent administration of the La Sota strain-containing vaccine AVIPEST was rather weak. Antibody levels rose somewhat after re-vaccination, but three treatments were necessary to reach a minimal protection at least. Such unsatisfactory results were obtained both in chickens kept at the institute, and in those kept on poultry farms. On the other hand, chickens on paramyxovirus-free farms reacted to vaccination with a typical rise of antibody levels.

The weak antibody response in chickens previously infected with NDV could, to a certain extent, substantiate the question, why so many chickens with low or even zero antibody levels are found in some flocks, yet the explanation remains to be expected. Of the posible causes, immunological tolerance to the virus, to which the chickens were exposed during the embryonic development, virus interference, and similar factors should be considered. Another explanation may consist in the formation of immunocomplexes during a long-termed persistence 
of the virus in the presence of antibodies. Further studies are necessary to elucidate this problem.

Lentogenic NDV strains were found both in birds with mild symptoms of a respiratory or intestinal disease, and in clinically normal ones. We have apparently confirmed the existence of the asymptomatic form of $\mathrm{ND}$, as described by Lancaster (1981) and reviewed by Hanson (1984). The presence of NDV in clinically normal chickens, which remained healthy when kept in satisfactory hygienic conditions, indicates, that at least some of the clinical signs observed in poultry farms could have been caused by other virus species, demonstrated in our experiments either directly by culture (adenoviruses, reoviruses, rotaviruses), or indirectly, i. e. by the presence of specific antibodies (infectious bursal disease).

The demonstration of the NDV circulation in poultry farms prompts us to a permanent vigillance. It is generally known that even apparently harmless agents can, under the contribution of various stress factors, display their limited pathogenic potential and induce a clinical disease.

\section{Nepředvídaný výskyt viru Newcastleské choroby u velmi mladých kuřat}

Ve střevním obsahu nevakcinovaných kuřat byly od 1 . dne po vylíhnutí do 25. dne stáŕi prokazovány izolačně i prímo elektronově mikroskopicky lentogenní kmeny viru Newcastleské choroby. Tyto viry byly detekovány dokonce i v samotných kuřecích embryích násadových vajec navzdory tomu, že ve žloutkových extraktech a později i u vylíhnutých kuřat byly prokazovány specifické mateřské protilátky. Virus Newcastleské choroby $\mathrm{z}$ kurat vymizel, aniž $\mathrm{u}$ nich indukoval aktivní tvorbu protilátek, a na vakcinaci tato kuřata reagovala tvorbou jen velmi nízkých a nevyrovnaných titrů protilátek. Jsou diskutovány možnosti transovariálního přenosu viru Newcastleské choroby.

\section{Непредвиденное наличие болезни Ньюкасла у цыплят на ранней стадии жизни}

В кишечном содержании невакцинированных цыплят с 1 дня после вылупливания по 25 день возраста были выявлены изоляционно и непсредственно электронно микроскопически лентогенные штаммы вируса болезни Ньюкасла. Упомянутые вирусы были установлены даже в эмбрионах яиц под наседкой несмотря на то, что в экстсактах желтков и позже, у вылуплившихся цыплят были обнаружены специфические материнские антитела. Вирус болезни Ньюкасла исчез, не индүцируя активное образование антител и упомянутые цыплята реагировали на вакциацию образованием немногочисленных и неровных титров антител. Обсуждаются возможности трансовариального переноса вируса болезни Ньюкасла.

\section{Acknowledgements}

The authors wish to thank the staff of Prof. Dr. R. P. Hanson's laboratory at the Department of Veterinary Science, University of Wisconsin, Madison, U.S.A., for excellent assistance and typing of a part of paramyxovirus strains, and Dr. D. J. Alexander from central Veterinary Laboratory, Weybridge, England, for their precise classification with the use of monoclonal antibodies. 


\section{References}

ALEXANDER, D. J.-MANVELL, R. J.-KEMP, P. A:-PARSONS, G. - COLLINS, M. S. -BROCKMANN, S.-RUSSELL, P. H.-LISTER, S. A.: Use of monoclonal antibodies in the characterisation of avian paramyxovirus type 1 (Newcastle disease virus) isolates submited to an international reference laboratory. Avian Path., 16, 1987: 553-565

ERDEI, J.- ERDEI, J. - KISSI, B. - MEDER, M. - SÁGHY, E. - PALYA, V. - TANYI, J. MÉSZÁROS, J.-LOMNICZI, B.: Identification by monoclonal antibodies of the vaccine (La Sota) type Newcastle disease virus (NDV) strains isolated from poultry flocks with respiratory symptoms. Magy. Állatorv. Lap., Budapest, 43, 1988: 267-271

FENNER, F.-BACHMANN, P. A.-GIBBS, E. P. J.-MURPHY, F. A.-STUDDERT, M. J. - WHITE, D. O.: Veterinary Virology, Acad. Press, Orlands, 1987, pp. 660

FONTAINE, M. O.-FONTAINE, M.-CHABAS, D.-BRION, A. J.: Presence of Newcastle disease-like agent in chicken embryo cells. Avian Dis., 9, 1965: 1-7

FRENCH, E. L. - StGEORGE, T. D. - PERCY, J. J.: Infection of chicks with recently isolated Newcastle disease viruses of low virulence. Aust. vet. J. 43, 1967: 404-409

HANSON, R. P.: In: Hitchner, S. B. et al. Isolation and identification of avian pathogens. Am. Assoc. of Avian Path., Texas, 1980, pp. 63-66

HANSON, R. P.: Newcastle disease. In: Hofstad, M. S. et al. Diseases of Poultry, 8th Ed., Iowa State Univ. Press, Ames, 1984, pp. 452-470

HILBINK, F.: Indications of the circulation of lentogenic Newcastle Disease field virus in broilers. Tijdschr. voor Diergeneesk., 112, 1987: 534-535

LANCASTER, J. E.: Newcastle disease - modes of spread. Vet. Bull., 33, 1963: 221-226

LANCASTER, J. E.: Newcastle disease - pathogenesis and diagnosis. World Poultry Science Journal, 37, 1981: 26-33.

SIMMONS, G. C.: The isolation of Newcastle disease virus in Queensland. Aust. vet. J., 43, 1967: $29-30$ 
Plate I.

Pospíšil Z. et al.: Unexpected Emergence ... pp. 263-270.

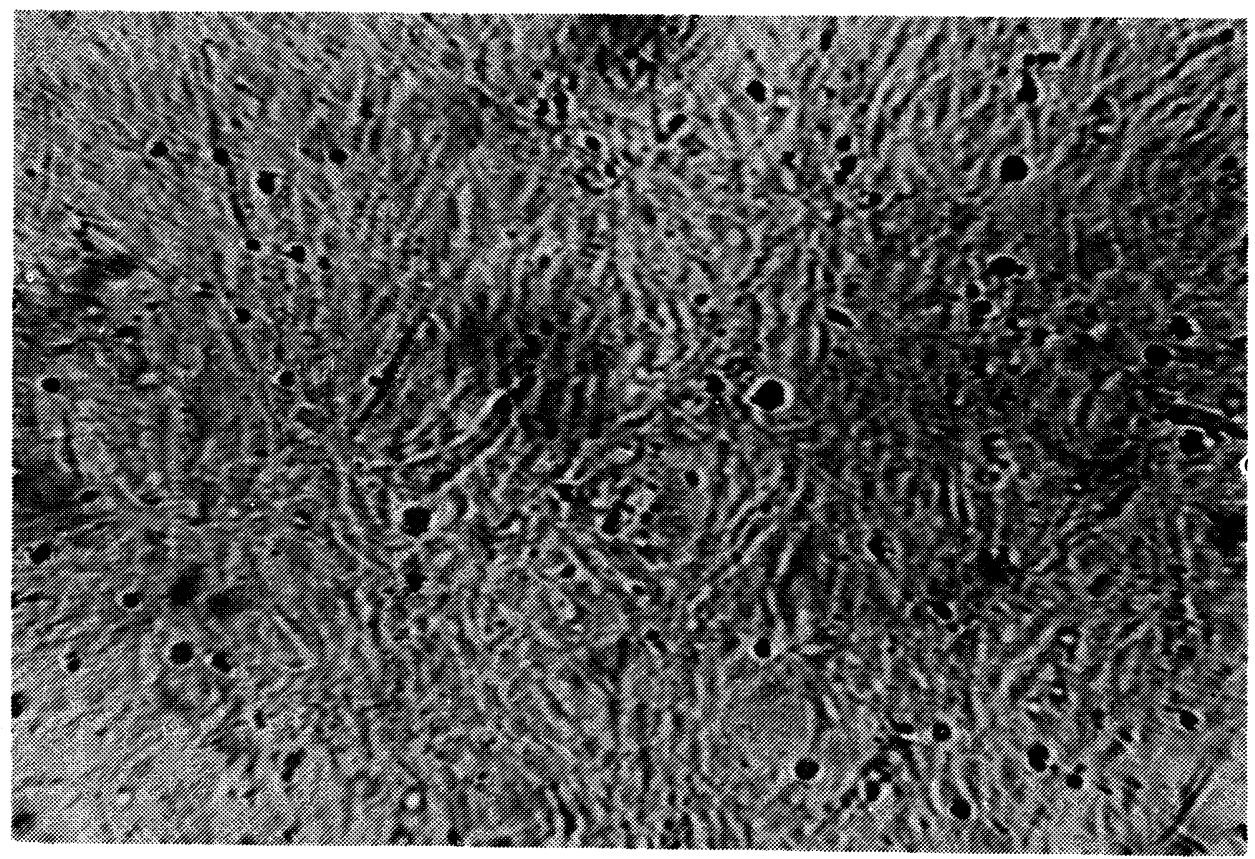

Fig. 1. Noninfected chicken embryo fibroblast monolayer.

Not stained, orig. magnification $6.3 \times 3.2$.

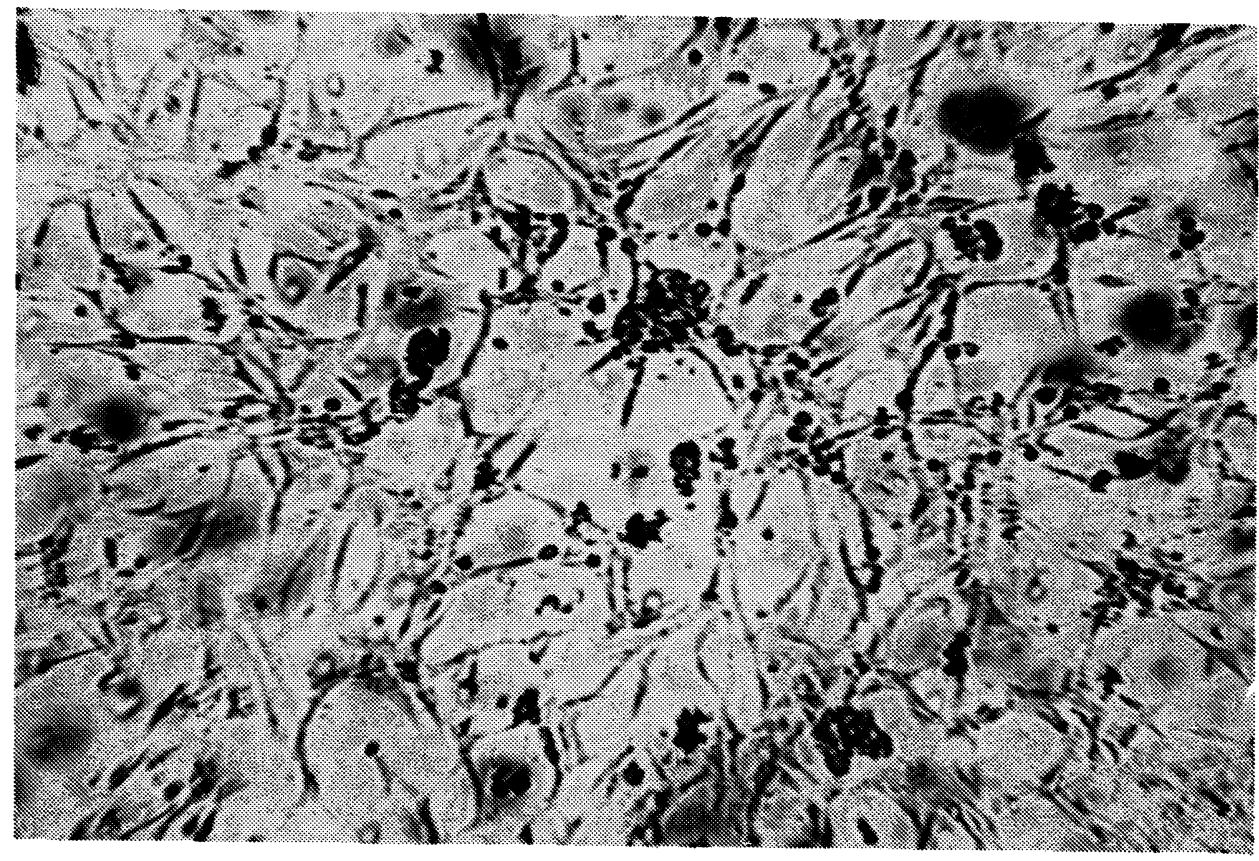

Fig. 2. CPE in embryonic chicken fibroblast cultures, produced in the 5th passage of the strain SL-93 96 hours after inoculation.

Not stained, orig. magnification $6.3 \times 3.2$. 


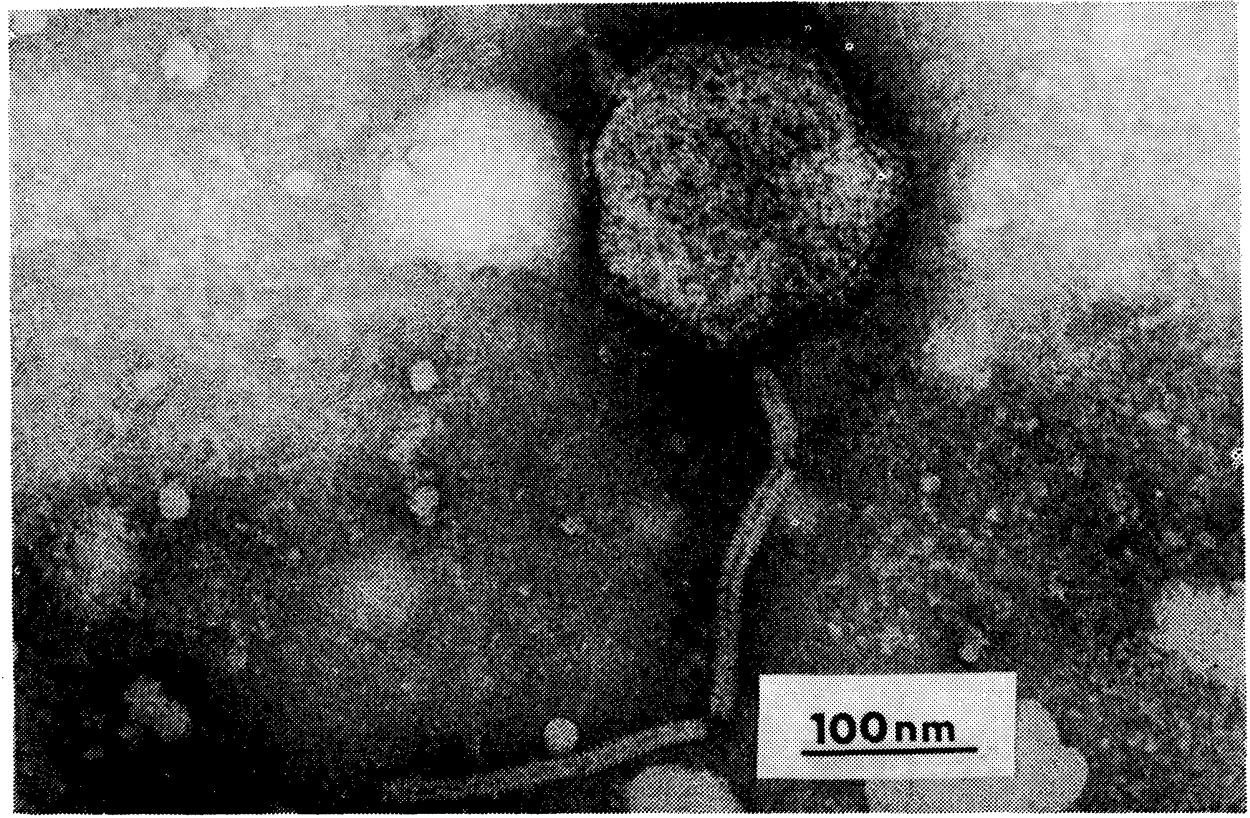

Fig. 3. NDV strain X-88 multiplied in allantoic fluid of chicken embryos, with a loose, helical nucleocapsid.

Negative staining by ammonium molybdate solution. Magnification $186000 \times$.

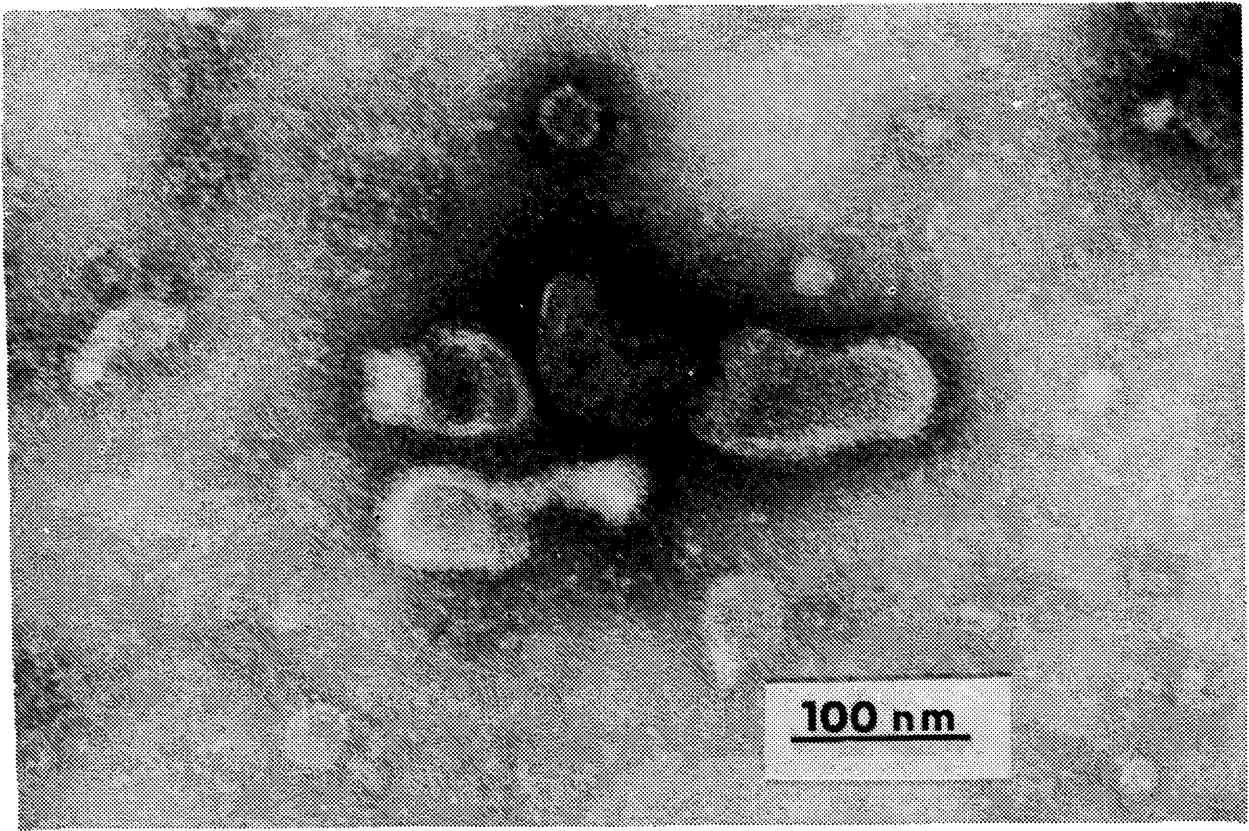

Fig. 4. NDV demonstrated in the gut content of a day-old chick. Negative staining by ammonium molybdate solution. Magnification $115000 \times$. 